\title{
OPEN Investigations on annual spreading of viruses infecting cucurbit crops in Uttar Pradesh State, India
}

\author{
Shweta Kumari ${ }^{1,3 凶}$, Krishnan Nagendran ${ }^{1,3}$, Vikas Dubey ${ }^{1}$, Bappa Das ${ }^{2}$, \\ Koshlendra Kumar Pandey ${ }^{1}$ \& Jagdish Singh ${ }^{1}$
}

During 2018 an intensive study was conducted to determine the viruses associated with cucurbitaceous crops in nine agroclimatic zones of the state of Uttar Pradesh, India. Total of 563 samples collected and analysed across 14 different cucurbitaceous crops. The results showed the dominance of Begomovirus (93\%) followed by Potyvirus (46\%), cucumber green mottle mosaic virus (CGMMV-39\%), Polerovirus (9\%), cucumber mosaic virus (CMV-2\%) and Orthotospovirus (2\%). Nearly $65 \%$ of samples were co-infected with more than one virus. Additionally, host range expansion of CMV, CGMMV and polerovirus was also observed on cucurbit crops. A new potyvirus species, zucchini tigre mosaic virus, earlier not documented from India has also been identified on five crops during the study. Risk map generated using ArcGIS for virus disease incidence predicted the virus severity in unexplored areas. The distribution pattern of different cucurbit viruses throughout Uttar Pradesh will help identify the hot spots for viruses and will facilitate to devise efficient and eco-friendly integrated management strategies for the mitigation of viruses infecting cucurbit crops. Molecular diversity and evolutionary relationship of the virus isolates infecting cucurbits in Uttar Pradesh with previously reported strains were understood from the phylogenetic analysis. Diverse virus infections observed in the Eastern Plain zone, Central zone and North-Eastern Plain zone indicate an alarming situation for the cultivation of cucurbits in the foreseeable future.

Cucurbits are economically important vegetables grown extensively in tropical and subtropical regions for human consumption. The family Cucurbitaceae comprises 825 species in 118 genera $^{1}$, of which about 100 species belonging to 37 genera are reported to be present in India. An area of nearly, 0.6 million hectares was dedicated to cucurbits cultivation with an annual production of 10.86 million tonnes in Uttar Pradesh during 2017-18 ${ }^{2}$. Diseases caused by viruses are among the limiting factors to cucurbits cultivation worldwide. More than 70 different viruses were reported to cause a wide range of diseases in cucurbits ${ }^{3}$. To date, viruses in the genera Begomovirus, Potyvirus, Cucumovirus, Tobamovirus, Tymovirus, Nepovirus, and Polerovirus have been described as potential threats in cucurbits cultivation across the world ${ }^{4-11}$. Viruses belonging to these genera are mainly transmitted by insect-vectors, although seed transmission has been reported in some species belonging to the genera Potyvirus, Cucumovirus, and Tobamovirus ${ }^{12-14}$. Recently, six viruses associated with cucurbit crops have been documented from Southern India. They are Papaya ring spot virus (PRSV), Cucumber green mottle mosaic virus (CGMMV), Zucchini yellow mosaic virus (ZYMV), Cucumber mosaic virus (CMV) and Begomovirus (tomato leaf curl New Delhi virus and squash leaf curl China virus) ${ }^{15}$.

Studies on the occurrence and distribution of viruses associated with cucurbit crops have been done only in southern India. So far, little effort has been made to determine the viruses infecting cucurbitaceous crops in Northern India. Therefore, the objective of the present study was to perform a comprehensive analysis of the occurrence, distribution and genetic diversity of viruses infecting cucurbit crops across Uttar Pradesh, India. Furthermore, an attempt was also made to map the epidemiological distribution and incidence proportion of the afore-mentioned viruses associated with cucurbit crops.

\footnotetext{
${ }^{1}$ ICAR-Indian Institute of Vegetable Research, Varanasi, Uttar Pradesh 221305, India. ${ }^{2}$ ICAR-Central Coastal Agricultural Research Institute, Old Goa, Goa 403402, India. ${ }^{3}$ These authors contributed equally: Shweta Kumari and K. Nagendran. ${ }^{\varpi}$ email: sweta.aau@gmail.com
} 


\section{Results}

Symptomatology and dynamics of disease incidence in Uttar Pradesh. A total of 563 samples from 14 different types of cucurbit crops were collected from nine agro-climatic zones of Uttar Pradesh (Supplementary Fig. 1). The samples showed virus like symptoms including mosaic, yellowing, mottling with chlorotic spots, distortion of leaves, puckering, yellowing, vein clearing, upward curling of leaves, necrosis, and stunting of plant growth with reduction in leaf size across farmers' fields (Fig. 1). Virus incidence was found in all agroclimatic zone of Uttar Pradesh and the incidence and distribution of the infected cucurbits viruses were varied based on the region of the collecting areas (i.e., the greater the growing area, the more the diseased samples collected). These three zones viz., Eastern, central and north-eastern plain zone accounts for more than 50 percent of total diseased samples (Supplementary Fig. 2). Based on symptomatology average disease incidence varied between different agro-climatic zones ranging between 11 and $27 \%$ with an overall mean incidence of $24 \%$. Our data revealed that the highest viral incidence was found in the Eastern and North-Eastern Plain zone (27\%), followed by the central zone (26\%) and the south-western zone (25\%), respectively. The lowest disease incidence (11\%) was recorded from the Bundelkhand zone (Fig. 2). Based on average field disease incidence, round melon (90\%), satputia (72\%), squash $(56.07 \%)$ and watermelon $(38.14 \%)$ were more prone to viral diseases (Table 1$)$.

Virus detection and analysis of distribution pattern. All samples collected during the study were subjected to PCR for Begomoviruses and RT-PCR for RNA viruses such as potyviruses (PRSV and ZYMV), Cucumovirus (CMV), Tobamovirus (CGMMV), Orthotospovirus (PBNV and WBNV), Potexvirus, Crinivirus and poleroviruses. Out of 563 collected cucurbits samples, 95.4\% (537/563) were found to be infected with viruses (either single or mixed infection). Despite showing virus like symptoms, the remaining $4.6 \%$ of samples tested negative for viruses. Universal and virus-specific primer pairs were used to test samples for eight virus genera, out of which samples were found to be positive for six genera (Potyvirus, Cucumovirus, Tobamovirus, Polerovirus, Orthotospovirus and Begomovirus). None of the samples were found to be positive for Potexvirus and Crinivirus. The relative frequency of viruses infecting cucurbit samples in our study showed dominance of Begomovirus (93\%) followed by Potyvirus (46\%), CGMMV (39\%), poleroviruses (9\%), CMV (2\%) and Orthotospovirus $(2 \%)$.

In general, the incidence of Begomovirus was higher in all the zones irrespective of the cucurbit crops. Diverse virus infection was observed only in samples tested from the Eastern Plain zone, Central zone and North-Eastern Plain zone while samples collected from the rest of the zones were positive for only potyviruses and CGMMV. Surprisingly, Polerovirus was primarily restricted to the Eastern plain zone, Central zone and North-Eastern Plain zone whereas Orthotospovirus and CMV were detected only among a few samples collected from the Eastern Plain zone and the North-Eastern Plain zone, respectively (Fig. 3). Potyvirus and CGMMV were the most frequent viruses detected among 64.3\% samples associated with 12 different cucurbit crops (Supplementary Fig. 3).

Expanded host range of viruses and new reports. Viruses detected in this study have already been documented and characterized from different parts of India. From this study, expansion of viral host ranges on different cucurbits was observed. Infection by poleroviruses such as cucurbit aphid borne yellow virus (CABYV) on squash; melon aphid borne yellow virus (MABYV) on ivy gourd; Luffa aphid borne yellow mosaic (LABYV) on sponge gourd, bitter gourd and pumpkin has been recorded for the first time from India. In addition, CMV on sponge gourd, ivy gourd and ridge gourd and CGMMV on long melon were also documented. Besides, Zucchini tigre mosaic virus (ZTMV) was observed newly in India on pumpkin, bottle gourd, bitter gourd, squash and cucumber.

Mixed infection. Virus-infected cucurbit samples showed a preponderance of mixed infection over single infection (Fig. 4). Among the tested samples, 366 samples (65\%) were found to be co-infected with more than one virus (Fig. 4A). Among single infection (169 samples), infection dominated with Begomovirus (90\%) followed by Orthotospovirus (6\%), Potyvirus (2\%) and CGMMV (2\%) (Fig. 4B). Of the mixed infection, $61 \%$ of samples (223 samples) were doubly infected in combinations of Begomovirus + Potyvirus, Begomovirus + CGMMV, Begomovirus + Polerovirus and Begomovirus + CMV (Fig. 4C). Moreover, triple infections were also found in $31 \%$ of samples (114 samples) in four different combinations as Begomovirus + Potyvirus + CGMMV, Begomovirus + Potyvirus $+\mathrm{CMV}$, Begomovirus + Polerovirus $+\mathrm{CMV}$, Begomovirus + Potyvirus + Polerovirus and the remaining $8 \%$ of samples (29 samples) were infected with a combination of four viruses (Begomovirus + Polerovirus + CGMMV + Potyvirus) (Fig. 4D). Among mixed infections, Potyvirus and/or CGMMV in combination with Begomovirus was observed to be more dominant.

Sequence analysis of viruses. In order to characterize the viruses infecting cucurbits in Uttar Pradesh state at the nucleotide level, selected samples were sequenced. Based on the sequencing, a CMV isolate infecting bitter gourd had $94.7 \%$ identity with the isolates reported earlier from Malaysia on cucumber (JN054637). The coat protein gene of the CGMMV isolate infecting cucurbits (bitter gourd, sponge gourd, cucumber, bottle gourd, long melon and snake gourd) was observed with more than $98 \%$ nucleotide identity with the CGMMV isolates recorded on various cucurbit crops characterised earlier from India. BLASTn analysis of nucleotide sequences amplified using a universal Polerovirus primer pair showed that three Polerovirus species (CABYV, MABYV and LABYV) were associated with different cucurbits of Uttar Pradesh. Similarly, sequence analysis using the BLASTn programme of the Nib region showed association of three potyvirus species (PRSV, ZYMV and ZTMV). In the coat protein region, PRSV showed more than $85 \%$ identity with isolates reported from India (EU475877) and China (KY933061); ZYMV showed $>98 \%$ identity with a Cucurbita pepo isolate (JN183062) reported from Iran; and ZTMV sequences showed $>85 \%$ identity with the sequences reported from France 


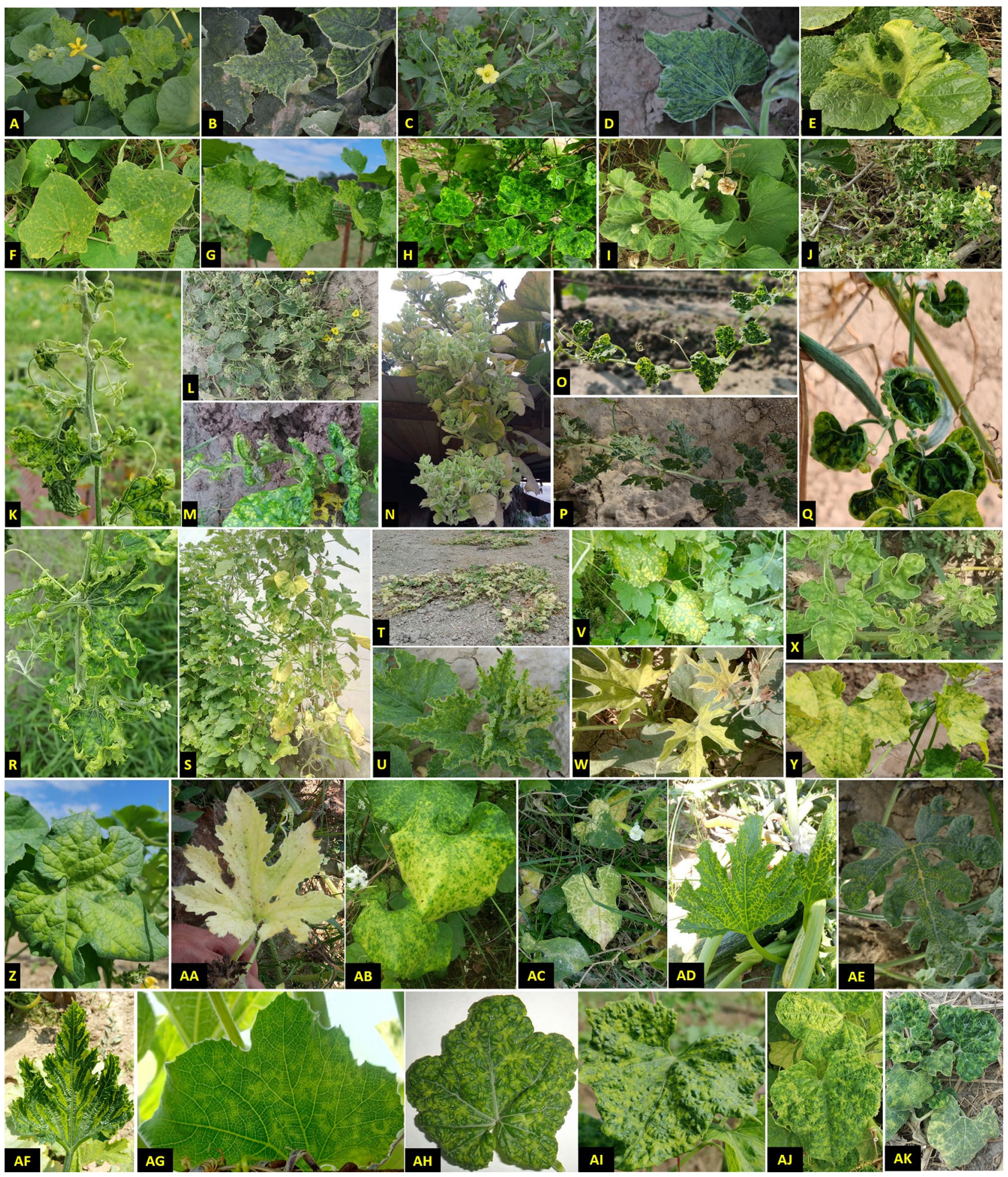

Figure 1. Symptoms of mosaic on Long melon (A), Cucumber (B), Bitter gourd (C), Bottle gourd (D), Pumpkin (E), Pointed gourd (F), Satputia (G), and Ivy gourd (H); leaf malformations on Bottle gourd (I), Bitter gourd (J,K), Cucumber (L), Sponge gourd (M), Bottle gourd (N), Satputia (O); leaf curl on Watermelon (P), Sponge gourd (Q), and Bitter gourd (R); chlorosis and yellowing on Musk melon (S), Pumpkin (T,U), Bitter gourd (V), Bottle gourd (W), Watermelon (X), Satputia (Y,Z), Ash gourd (AA), and Snake gourd (AB); clearing of veins in Ponited gourd (AC), Squash (AD) and Watermelon (AE); vein banding in Squash (AF); ring spots on Bottle gourd leaves (AG); and puckering and blistering of leaves on sponge gourd (AH), Satputia (AI), Ridge gourd (AJ) and Pumpkin (AK). 


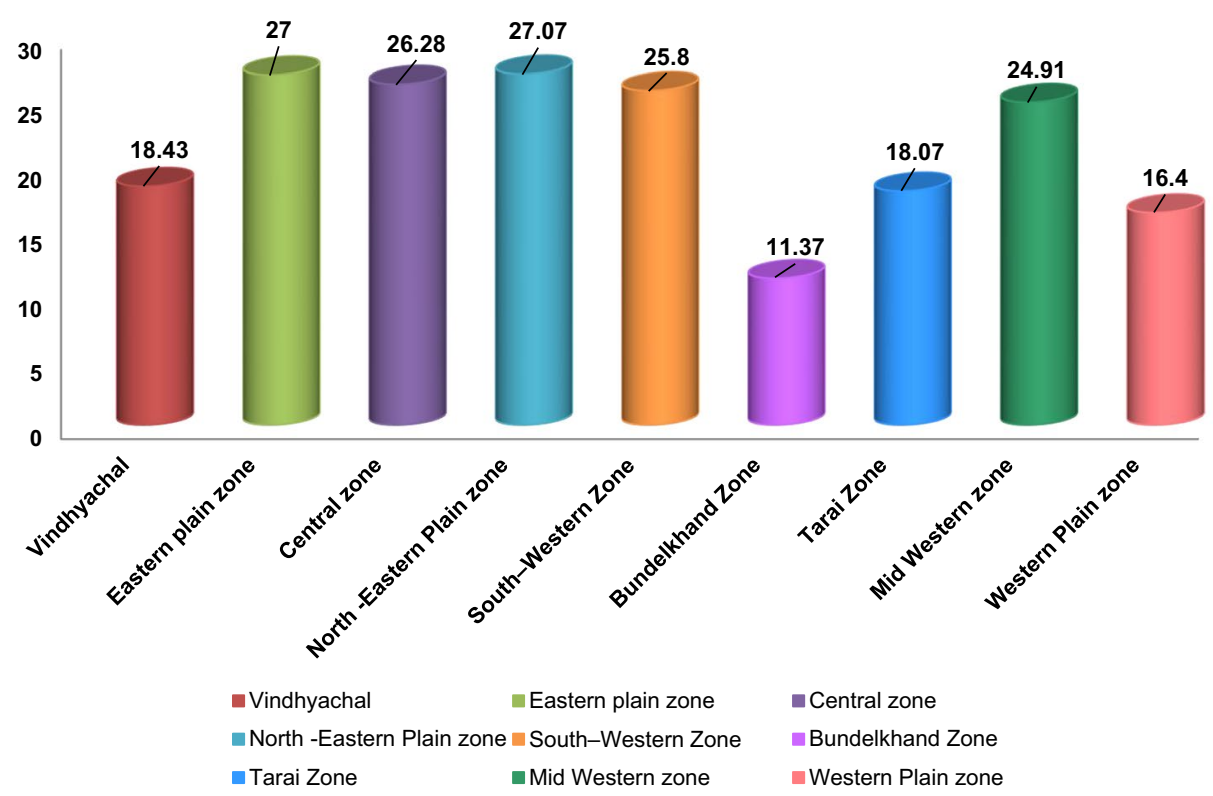

Figure 2. Viral disease incidence on cucurbits across the different agroclimatic zones of Uttar Pradesh.

\begin{tabular}{|l|l|l|l|}
\hline Crops & No. of present viruses & Disease incidence range (\%) & Average disease incidence \\
\hline Bottle gourd & $\begin{array}{l}\text { POTYVIRUS, CGMMV, POLEROVIRUS, BEGOMOVI- } \\
\text { RUS }\end{array}$ & $4-60$ & 17.62 \\
\hline Sponge gourd & $\begin{array}{l}\text { POTYVIRUS, CGMMV, CMV, POLEROVIRUS, BEGO- } \\
\text { MOVIRUS }\end{array}$ & $7-60$ & 30.14 \\
\hline Bitter gourd & $\begin{array}{l}\text { POTYVIRUS, CGMMV, CMV, POLEROVIRUS, BEGO- } \\
\text { MOVIRUS }\end{array}$ & $6-40$ & 23.46 \\
\hline Ridge gourd & POTYVIRUS, CMV, BEGOMOVIRUS & $0-10$ & 10.00 \\
\hline Snake gourd & CGMMV, POTYVIRUS, BEGOMOVIRUS & $5-13$ & 9.33 \\
\hline Ivy gourd & $\begin{array}{l}\text { POTYVIRUS, CGMMV, POLEROVIRUS, BEGOMOVI- } \\
\text { RUS }\end{array}$ & $2-8$ & 4.67 \\
\hline Pumpkin & $\begin{array}{l}\text { POTYVIRUS, CGMMV, POLEROVIRUS, BEGOMOVI- } \\
\text { RUS }\end{array}$ & $10-50$ & 26.68 \\
\hline Squash & $\begin{array}{l}\text { POTYVIRUS, CGMMV, POLEROVIRUS, BEGOMOVI- } \\
\text { RUS }\end{array}$ & $30-89$ & 56.07 \\
\hline Satputia & BEGOMOVIRUS & $0-72$ & 72.00 \\
\hline Cucumber & POTYVIRUS, CGMMV, BEGOMOVIRUS & $2-25$ & 11.52 \\
\hline Watermelon & POTYVIRUS, WBNV, CGMMV, BEGOMOVIRUS & $14-90$ & 38.14 \\
\hline Muskmelon & CGMMV, BEGOMOVIRUS & $7-12$ & 9.50 \\
\hline Long melon & POTYVIRUS, CGMMV, BEGOMOVIRUS & $5-50$ & 33.40 \\
\hline Round melon & WBNV & $0-90$ & 90.00 \\
\hline
\end{tabular}

Table 1. Disease incidence of viruses in different cucurbit crops collected across Uttar Pradesh.

(KC345605, KC345607-8). Watermelon bud necrosis virus (WBNV) was the only Orthotospovirus found associated with both round melon and watermelon having identity of $>95 \%$ with Indian isolates (Table 2 ).

Phylogenetic analysis of viruses. Phylogenetic analysis based on the nucleotide sequence of the 2a fragment showed that a CMV isolate infecting cucurbits shared ancestry with the CMV reported on tomato, snake gourd, bottle gourd, pepper and banana from India (Fig. 5a). Based on the sequence analysis, it has been determined that a CMV strain belonging to serogroup IB is infecting cucurbits in Uttar Pradesh. Similarly, sequence analysis based on the coat protein gene of the CGMMV isolates (Bottle gourd, bitter gourd, sponge gourd, snake gourd, long melon and cucumber) revealed prevalence of two distinct groups in India. The first group forms a cluster with isolates reported from Australia, Greece, China, Korea, Japan and India (clade A) while the second group (clade B) comprises only Indian isolates (Fig. 5b). In the case of PRSV and ZTMV (potyviruses), based on the Nib region, PRSV and ZTMV isolates grouped under two separate clades. Within PRSV isolates, two distinct clades were observed (A and B). One clade shared ancestry with the PRSV strains reported from different 


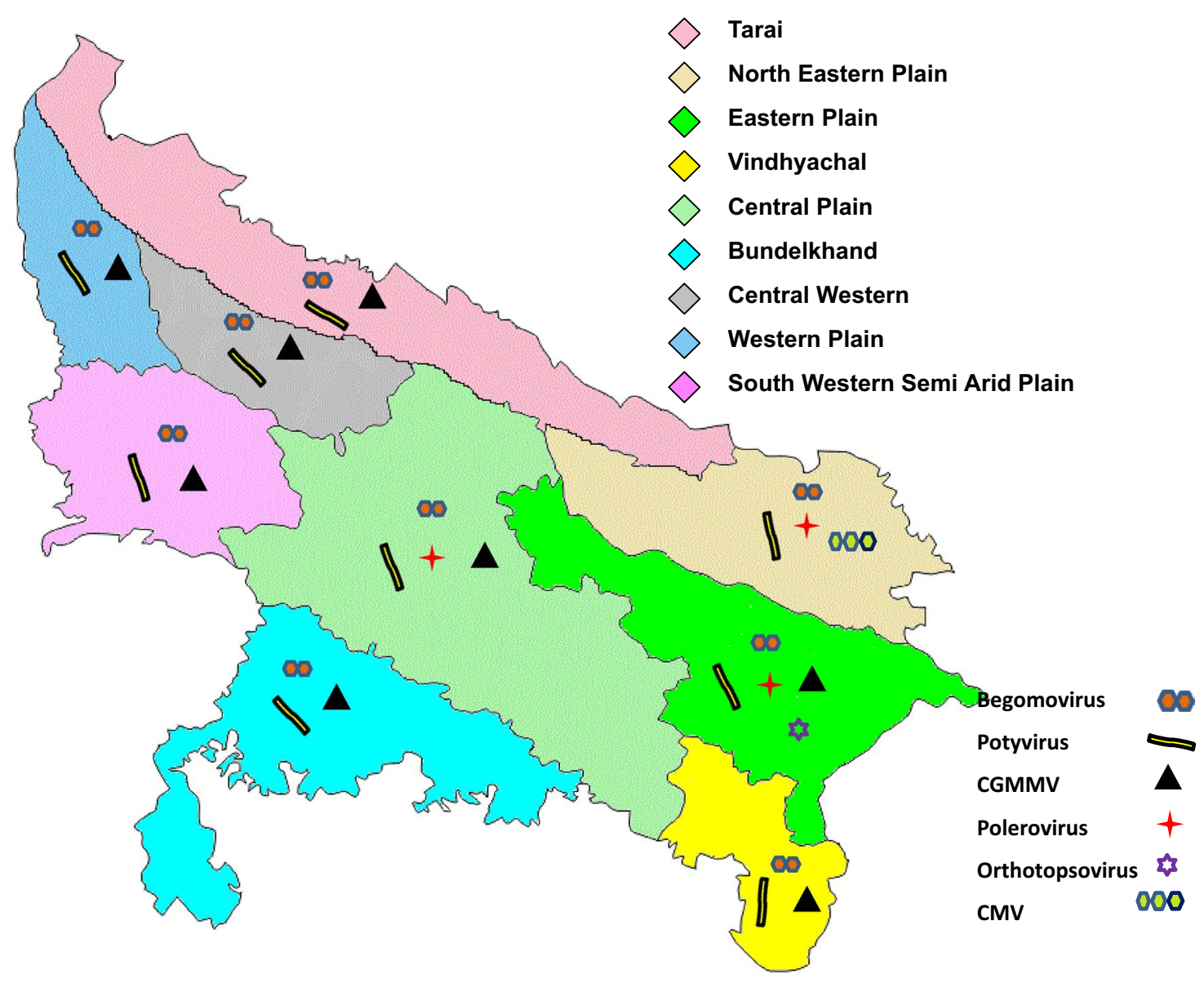

Figure 3. Map of agro-climatic zones of UP showing virus disease incidence and their virus distribution.

countries (clade A) and the second clade (B) clustered particularly with Indian isolates (Fig. 5c). Furthermore, phylogenetic tree generated based on the coat protein region of PRSV formed separate clades from the previously reported isolates from various countries including India (except an Indian PRSV-W strain, EU475877) (Fig. 5d). Being a new virus to India, ZTMV isolates were found to have a close relationship with France isolates (Fig. 5c). With reference to ZYMV, all the study isolates were grouped with isolates reported from Asia, Europe, Africa and South America sharing their common ancestry (Fig. 5e). Similar analysis of WBNV isolates infecting round melon and watermelon typically displayed the same centre of origin with northern India isolates reported earlier and are clearly distinct from the southern India isolates (Fig. 5f). Phylogenetic analysis of polerovirus sequence showed 2 distinct clades of poleroviruses, one comprising CABYV and MABYV and the other comprising LABYV (Fig. 5g).

Generation of risk map of virus disease incidence using ArcGIS. Virus distribution and incidence proportion for the four viruses were mapped using the functionalities of ArcGIS 9.1 software and the results are presented in Fig. 6. The maximum area under overall virus disease incidence fall under the category of 10-25\% followed by $25-50 \%$ (Fig. 6A). The highest incidence was predicted with Polerovirus (50-89\%) (Fig. 6B) whereas 25-50\% incidence for CGMMV (Fig. 6C), Begomovirus (Fig. 6D) and Potyvirus (Fig. 6E) were observed. Since the survey points for CMV and Orthotospovirus are 3 and 2, these viruses were not mapped. The optimum numbers of power values were 7.59, 1, 5.28, 1 and 1 for Polerovirus, CGMMV, Potyvirus, Begomovirus and overall disease incidence, respectively. The green areas in the interpolated maps indicate very low to low disease incidences while the areas with orange to red colouration indicated moderate to high disease incidences. Around $75 \%$ area of Uttar Pradesh state fall under 10-25\% disease incidence category for Begomovirus, Potyvirus and CGMMV whereas majority area of the polerovirus infection falls under $25-50 \%$ disease incidence category (Table 3 ).

\section{Discussion}

In this study, we explored cucurbit fields in different regions of Uttar Pradesh state (UP) (nine agro-climatic zones). Results showed disease incidences in different zones varied significantly. Association of one or more virus species belonging to the genera Begomovirus, Potyvirus, Cucumovirus, Tobamovirus, Orthotospovirus and Polerovirus were detected. Among the 563 samples tested, 26 samples did not test positive for any tested viruses. These samples may have been infected by viruses other than those tested in this study. In cucurbits, Begomovirus 


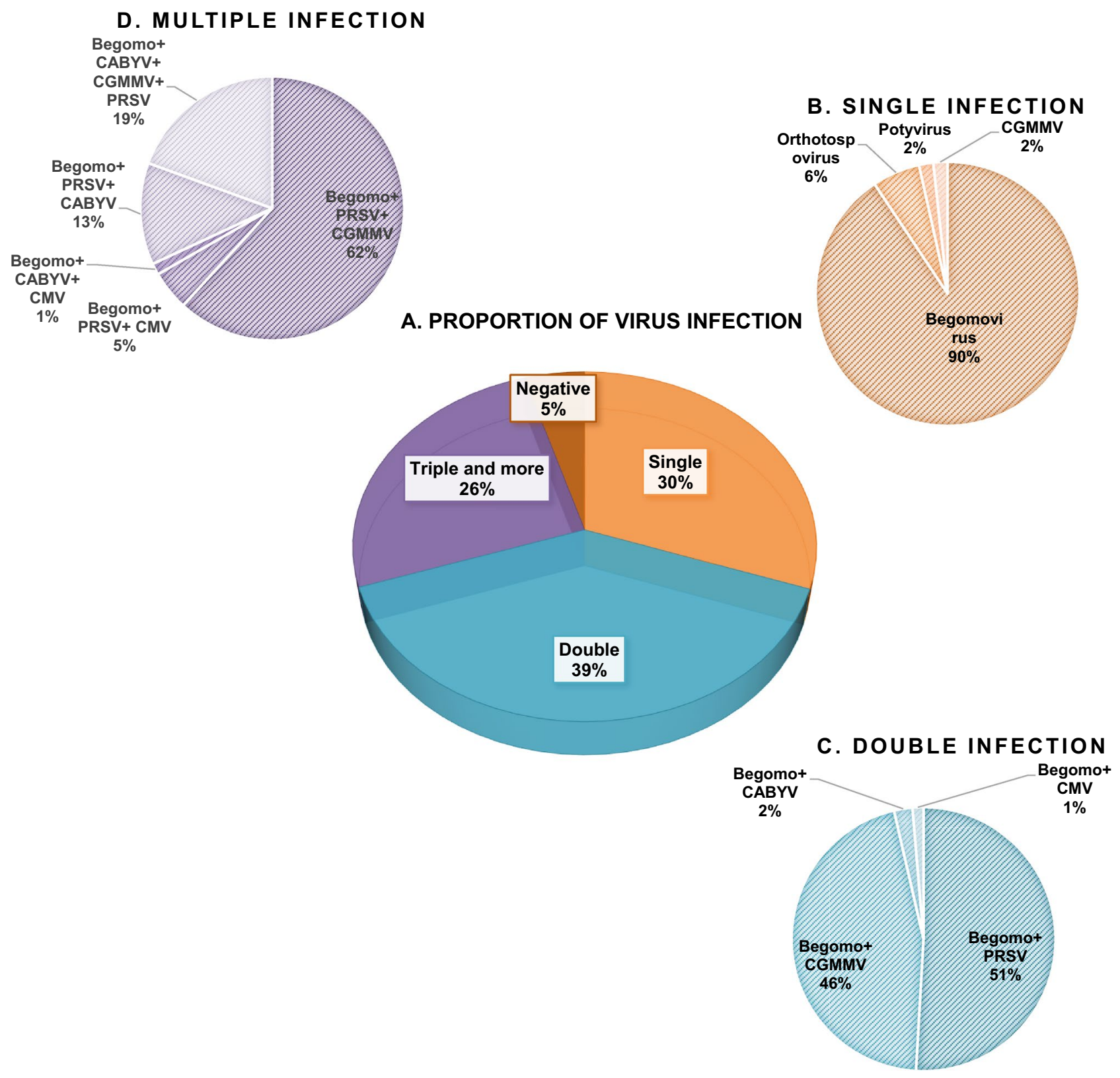

Figure 4. Status of mixed virus infection in cucurbits samples.

infection was the most identified, infecting 523 samples collected from thirteen different cucurbit crops across the UP state. Our result is consistent with previous finding of Nagendran et al. ${ }^{15}$ that Begomoviruses are the most dominant virus (98.6\%) in cucurbit samples collected from southern India. High adaptability of Begomovirus, polyphagous nature of its vectors and the continuous availability of other host plants plays a major role in the Begomovirus infection.

The next to Begomovirus, Potyvirus was detected among 254 samples collected from 10 cucurbit crops (except watermelon, satputia, musk melon and round melon). Due to the diverse nature of potyviruses prevailing in the cucurbits ecosystem, a single universal primer pair (PNIbF1/PCPR1) could not amplify the majority of samples. Therefore, different sets of primer pairs were used for potyvirus detection (Table 4). Earlier studies from India have documented only the occurrence of PRSV and ZYMV on cucurbits ${ }^{5,15}$. ZYMV isolates from the current study were closely related to previously reported Indian isolates regardless of host, geographic location and year of collection as documented by Chikh-Ali et al. ${ }^{16}$ in Syria. In the present study, in addition to these two potyviruses, occurrence of ZTMV has also been documented for the first time in India. Though diverse potyviruses were infecting cucurbits in India, much diversity was observed only with PRSV, but ZYMV and ZTMV seemed to have low diversity within the species. The widespread distribution of PRSV in single and mixed infections among tested samples indicated that it is an already established virus rather than a recent introduction. In contrast, CGMMV was detected among 223 samples in 11 different crops except for satputia, ridge gourd and round melon. CGMMV isolates in this study showed less diversity irrespective of the host and location of sample collection. Due to its seed transmission nature, single strains of CGMMV might have spread across the country. As 


\begin{tabular}{|c|c|c|c|c|c|}
\hline Virus & Isolate & Crop & GenBank Acc. no & $\begin{array}{l}\text { Percent identity in BLAST with reference } \\
\text { isolate }\end{array}$ & Reference isolate \\
\hline CMV & UPCMV BG & Bitter gourd & MT768062 & $94.69 \%$ & \begin{tabular}{|l|} 
JN054637 \\
\end{tabular} \\
\hline \multirow{11}{*}{ CGMMV } & UPCGMMV BOG1 & \multirow{2}{*}{ Bottle gourd } & MT636375 & \multirow{2}{*}{$98.72-99.09$} & \multirow{2}{*}{ MH271435 } \\
\hline & \begin{tabular}{|l} 
UPCGMMV BOG2 \\
\end{tabular} & & \begin{tabular}{|l|} 
MT636376 \\
\end{tabular} & & \\
\hline & UPCGMMVLM & Long melon & MT636380 & \multirow{2}{*}{$99.46-99.64$} & \multirow{2}{*}{ MH271435 } \\
\hline & UPCGMMVCU & Cucumber & MT636384 & & \\
\hline & UPCGMMVBG & Bitter gourd & \begin{tabular}{|l|} 
MT636381 \\
\end{tabular} & \multirow{2}{*}{$98.93-99.08 \%$} & \multirow{2}{*}{ DQ767631 } \\
\hline & \begin{tabular}{|l|} 
UPCGMMVSPG1 \\
\end{tabular} & Sponge gourd & MT636382 & & \\
\hline & UPCGMMV BOG3 & Bottle gourd & MT636377 & 99.64 & MH271409 \\
\hline & UPCGMMVSPG2 & Sponge gourd & MT636383 & \multirow{4}{*}{ 96.05-99.09 } & \multirow{4}{*}{ MF510469 } \\
\hline & UPCGMMVSNG & Snake gourd & MT636385 & & \\
\hline & UPCGMMV BOG4 & Bottle gourd & MT636378 & & \\
\hline & UPCGMMV BOG5 & Bottle gourd & MT636379 & & \\
\hline \multirow{8}{*}{ PRSV } & UPPRSV SPG1 & Sponge gourd & MT636386 & 86.56 & KT895257 \\
\hline & UPPRSV SPG2 & Sponge gourd & MT636387 & 84.48 & MN203187 \\
\hline & UPPRSV PUM1 & Pumpkin & MT648432 & 89.61 & EU475877 \\
\hline & UPPRSV SNG1 & \multirow{2}{*}{ Snake gourd } & MT636389 & \multirow{2}{*}{$92.02-90.59$} & \multirow{2}{*}{ KP743981 } \\
\hline & UPPRSV SNG2 & & MT636390 & & \\
\hline & UPPRSV PUM & Pumpkin & MT636388 & 85.82 & KF002603 \\
\hline & \begin{tabular}{|l} 
UPPRSV SNG \\
\end{tabular} & Snake gourd & MT648434 & \multirow{2}{*}{$85.03-85.07$} & \multirow{2}{*}{ KY933061 } \\
\hline & UPPRSV PUM2 & Pumpkin & MT648433 & & \\
\hline \multirow{3}{*}{ ZYMV } & UPZYMV SPG1 & Sponge gourd & MT636391 & \multirow{3}{*}{$98.64-98.87$} & \multirow{3}{*}{ JN183062 } \\
\hline & UPZYMV CU1 & Cucumber & MT636392 & & \\
\hline & UPZYMV SPG2 & Sponge gourd & MT636393 & & \\
\hline \multirow{6}{*}{ ZTMV } & UPZTMV BOG1 & Bottle gourd & MT755615 & 86.41 & KC345607 \\
\hline & UPZTMV BOG2 & Bottle gourd & MT755616 & 87.03 & KC345608 \\
\hline & UPZTMV CU & Cucumber & MT755617 & 85.56 & KC345607 \\
\hline & UPZTMV BG & Bittergourd & MT755618 & 87.80 & KC345605 \\
\hline & UPZTMV PUM & \begin{tabular}{|l|} 
Pumpkin \\
\end{tabular} & MT755614 & 87.46 & MK988416 \\
\hline & UPZTMV SQ & Squash & MT755613 & 86.02 & KC345605 \\
\hline \multirow{5}{*}{ LABYV } & UPPOL BG1 & \multirow{2}{*}{ Bitter gourd } & MT622665 & \multirow{2}{*}{82.56} & \multirow{2}{*}{ KR476808 } \\
\hline & UPPOL BG2 & & MT622666 & & \\
\hline & UPPOL PUM1 & Pumpkin & MT622671 & 84.63 & KR476808 \\
\hline & \begin{tabular}{|l|} 
UPPOL PUM2 \\
\end{tabular} & \begin{tabular}{|l|} 
Pumpkin \\
\end{tabular} & MT622672 & 84.73 & KF427702 \\
\hline & UPPOL SPG1 & Sponge gourd & MT622667 & 83.72 & KF427702 \\
\hline \multirow{3}{*}{ MABYV } & UPPOL SQ1 & Squash & MT622669 & 93.06 & JQ700307 \\
\hline & \begin{tabular}{|l|} 
UPPOL SQ2 \\
\end{tabular} & Squash & MT622670 & 93.44 & JQ700307 \\
\hline & UPPOL IVY1 & Ivy gourd & MT622673 & 93.63 & JQ700307 \\
\hline \multirow{2}{*}{ WBNV } & VNS WM1 & Watermelon & MN462627 & 95.53 & EU373762 \\
\hline & VNS RM1 & Round melon & MH717082 & 95.41 & EU373763 \\
\hline
\end{tabular}

Table 2. List of isolates used in this study.

different cucurbit crops are cultivated side by side in the Indian subcontinent and harvested manually, mechanical transmission likely plays a major role in the expansion of virus host range.

Besides, CMV was the least distributed virus detected only among 12 samples of bitter gourd, sponge gourd and ridge gourd. Though CMV has wide host range, the reason for its limited distribution among cucurbits remains unclear. Similarly, limited occurrence of CMV in cucurbits from commercial growers among the several viruses tested has been documented earlier ${ }^{15,27}$. Despite the fact that Orthotospovirus has been well documented on various cucurbits in the Indian subcontinent, only 10 samples of round melon and watermelon crops were found to be infected with Orthotospovirus in the UP state. There have been several reports on the occurrence of Orthotospovirus in southern India but not from northern India. Recently, research from our laboratory documented for the first time in India Orthotospovirus infection on cucurbits including PBNV on bitter gourd ${ }^{20}$ and WBNV on round melon ${ }^{28}$. This study further reinforces the previous findings of Orthotospovirus being an emerging threat to the cultivation of vegetable crops in northern India. Three species of cucurbit infecting poleroviruses (CABYV, MABYV and LABYV) were identified and characterized in pumpkin, bitter gourd, sponge gourd, squash and ivy gourd. A previous study from southern India has documented the infection of bitter gourd and teasel gourd by CABYV ${ }^{29,30}$. Findings from the present study further confirm the existence of 
A

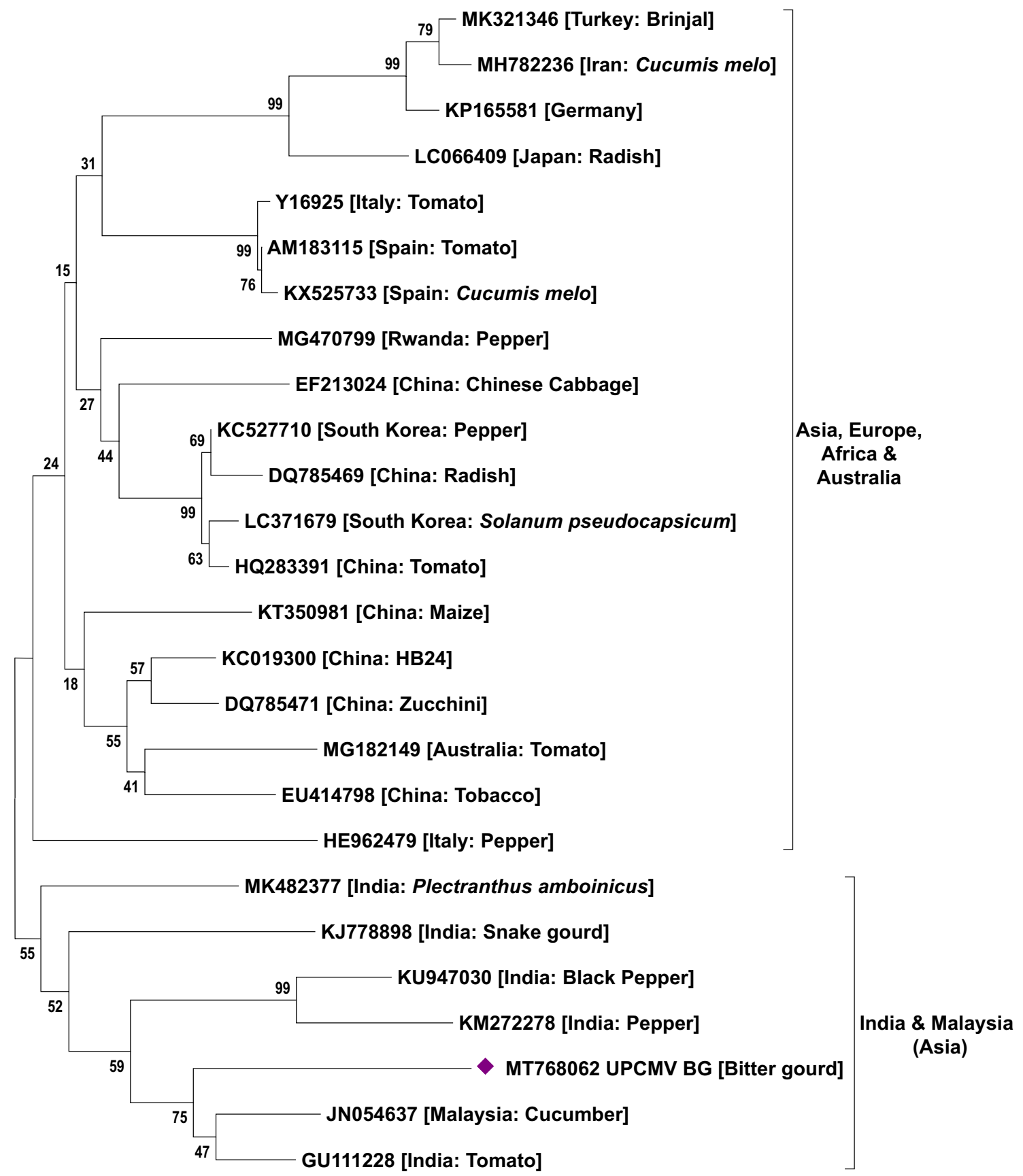

0.01

Figure 5. Phylogenetic analysis of (a) CMV infecting cucurbits in Uttar Pradesh state with other CMV isolates earlier reported based on 2a region. (b) CGMMV infecting cucurbits in Uttar Pradesh state with other CGMMV isolates reported earlier based on coat protein gene. (c) Potyviruses (PRSV and ZTMV) infecting cucurbits in Uttar Pradesh state with other earlier reported isolates based on Nib region. (d) PRSV infecting cucurbits in Uttar Pradesh state with other PRSV isolates reported earlier based on coat protein gene. (e) ZYMV infecting cucurbits in Uttar Pradesh state with other ZYMV isolates reported earlier based on coat protein gene. (f) WBNV infecting cucurbits in Uttar Pradesh state with other WBNV isolates reported earlier based on coat protein gene. (g) Poleroviruses infecting cucurbits in Uttar Pradesh state with other earlier reported isolates based on coat protein gene. Trees were generated with 1000 bootstrap replications using neighbour joining method in MEGA 7.0 software. 
B

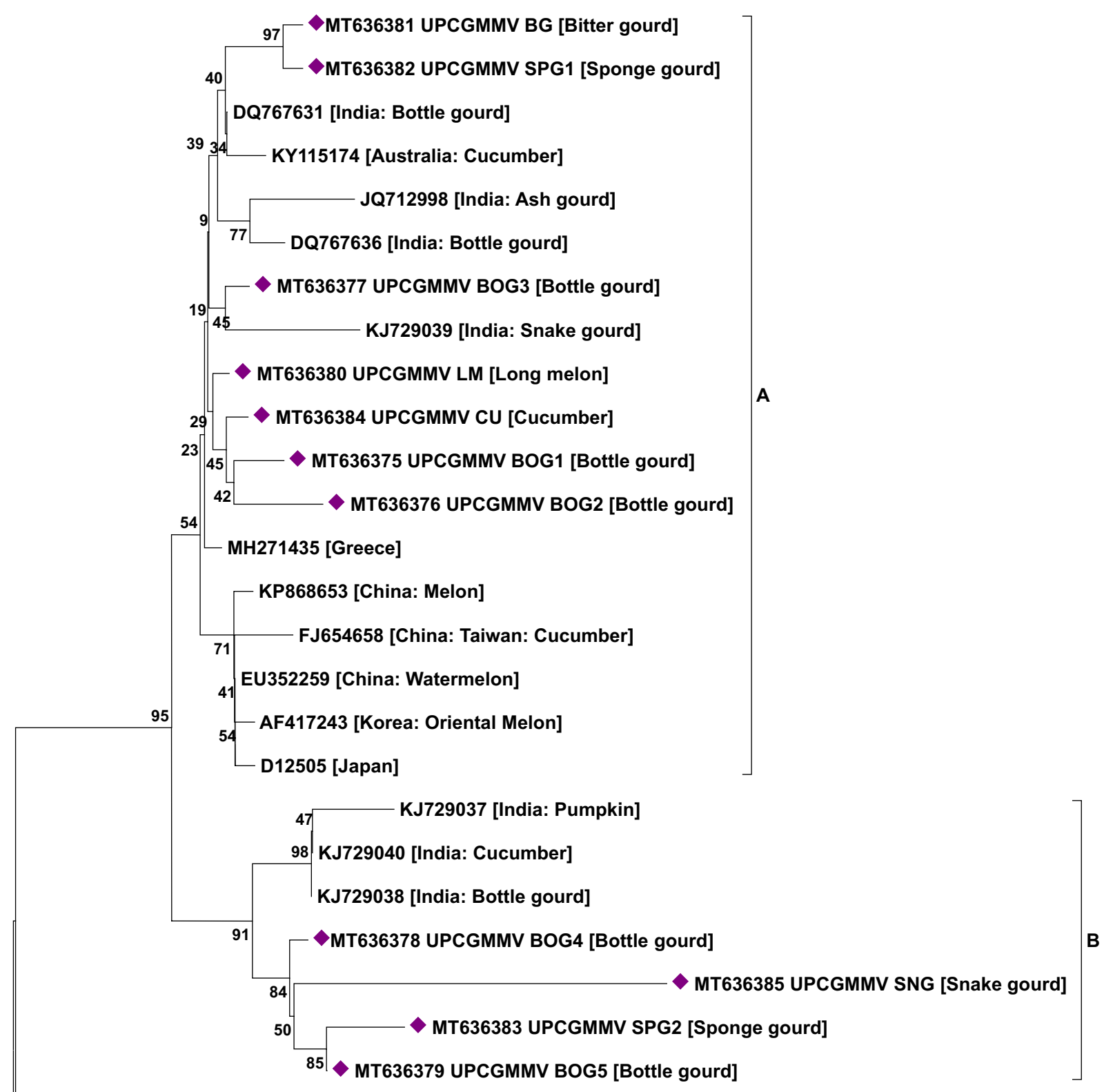

KF155232 [Israel: Cucumber]

GQ411361 [Spain: Cucumber]

100 GQ495274 [Russia: Cucumber]

0.01

Figure 5. (continued) 
C

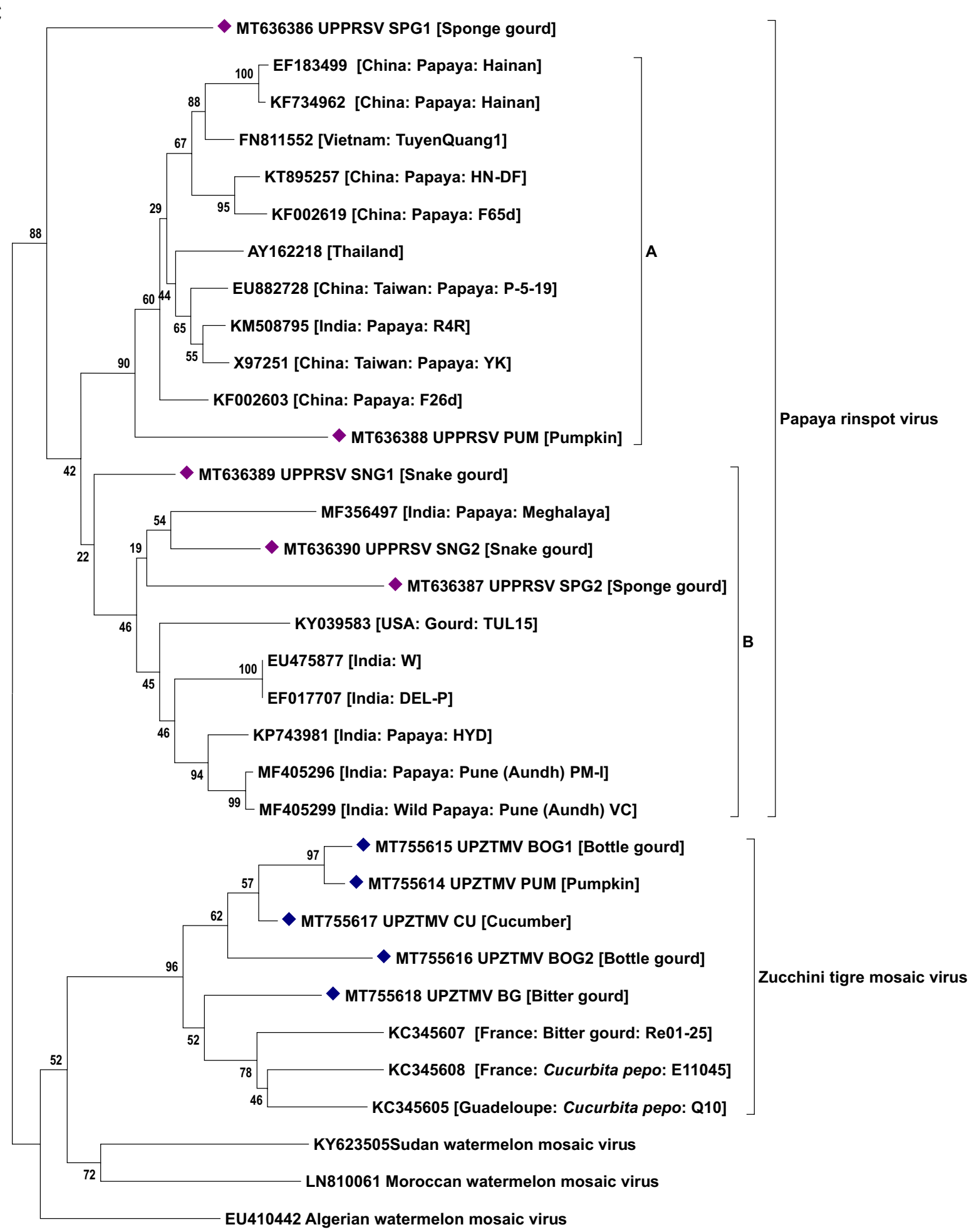

$\lcm{0.02}$

Figure 5. (continued) 


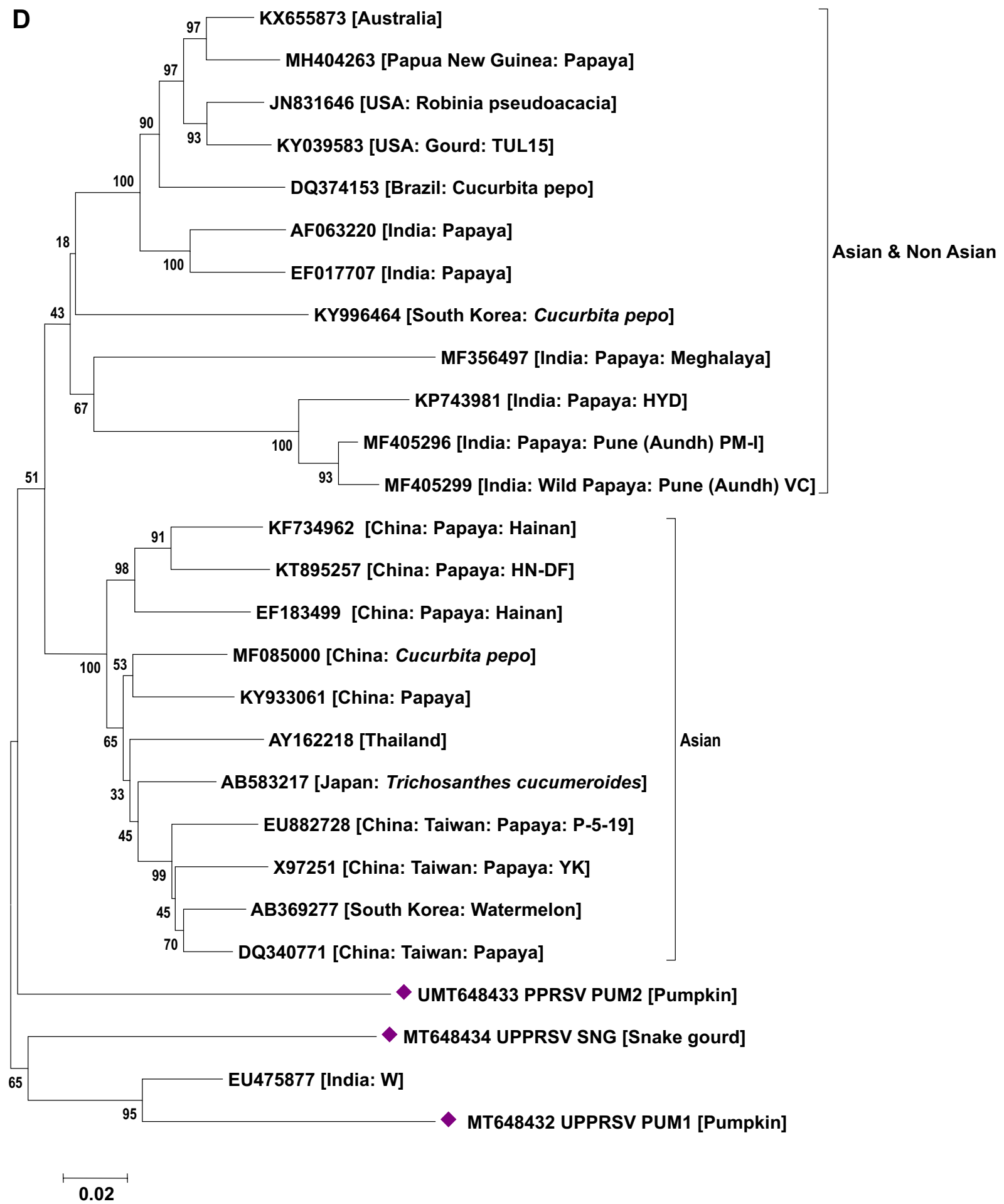

Figure 5. (continued) 


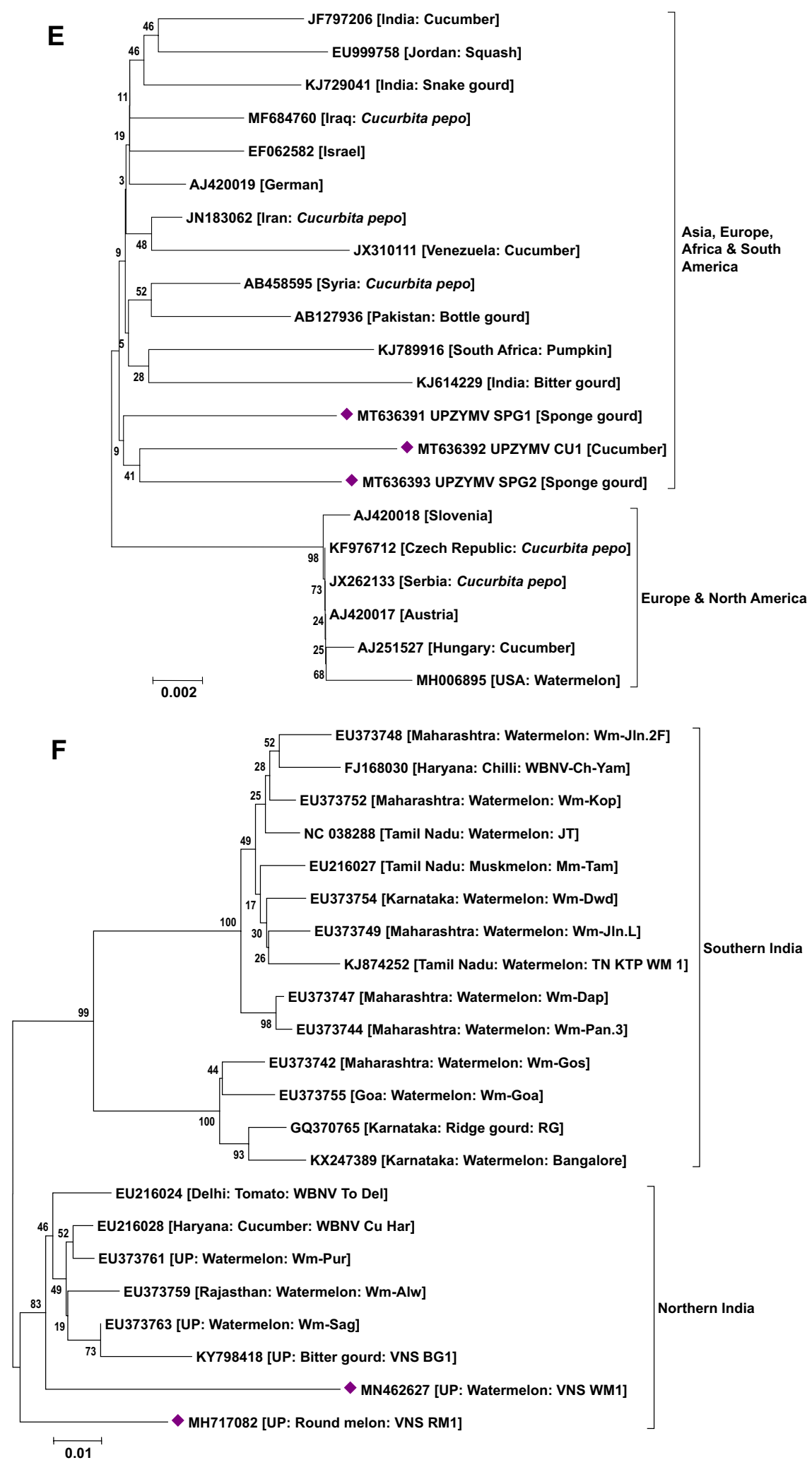

Figure 5. (continued) 


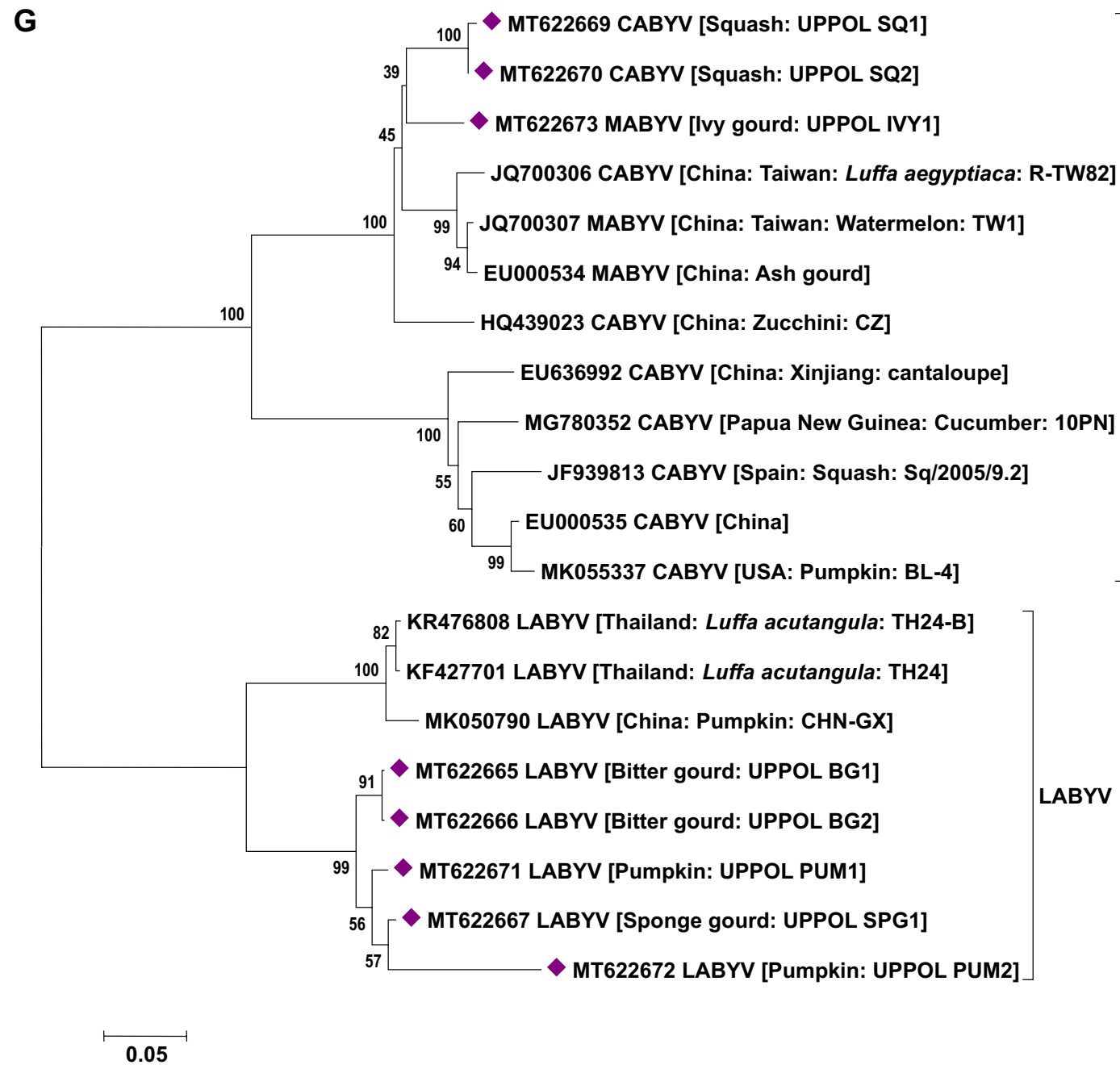

Figure 5. (continued)

CABYV on cucurbits cultivated in northern India with an expanded host range, and the existence of other species (MABYV and LABYV) may be indicative of its emergence in India.

Further our study shows the predominance of mixed infection (64\%) over single infection (32\%) in infected samples. Although up to $32 \%$ single infection due to Begomoviruses, causing mosaic and mottling symptoms was observed in cucurbit samples, double infection by Begomovirus coupled with Potyvirus/ Tobamovirus/ Polerovirus (44\%) was by far the most common in tested samples. Infection of cucurbits by triple viruses (Begomovirus + Potyvirus + Tobamovirus) was recorded in $16 \%$ of the total tested samples. Similar results have been observed in India and Oklahoma with preponderance of double infection over triple infection ${ }^{15,27}$. Additionally, Kone et al. ${ }^{31}$ observed average multiple virus infections among $15 \%$ of cucurbits samples in Cote d'Ivoire. Interestingly, mixed infection of cucurbits by four viruses (Begomovirus + Potyvirus + Tobamovirus + Polerovirus) was observed in very few samples as previously reported on squash, melon and cucumber in $\operatorname{Iran}^{32}$.

The main aim of risk mapping of ArcGIS is to find the hazard level of the virus which is causing threat to crop cultivation $^{33,34}$. It provides map showing probability of the occurrence of disease in the unexplored area based on the data collected from few pockets of the state. This gives clarity about the hot spot and cold spot for each virus separately as well as for the overall virus diseases infecting cucurbits. To our knowledge, this is the first of its kind in generating the risk map for virus diseases infecting cucurbits.

Overall, the present work outlined the current status of cucurbits viruses in UP state and provided conclusive evidence of viral diversity and the potential presence of new viruses currently emerging in this area. The distribution pattern of different cucurbit viruses in this region will help to identify the hot spots for viruses and will facilitate to devise efficient and eco-friendly integrated management strategies for management. Additionally, we identified many new viruses such as CMV on sponge gourd, bitter gourd and ridge gourd; CGMMV on long melon; Polerovirus on squash, pumpkin, ivy gourd and sponge gourd; and ZTMV on pumpkin, bottle gourd, bitter gourd, squash and cucumber. Further studies are needed to explore and characterize new and unidentified viruses which have been reported from different parts of world. 


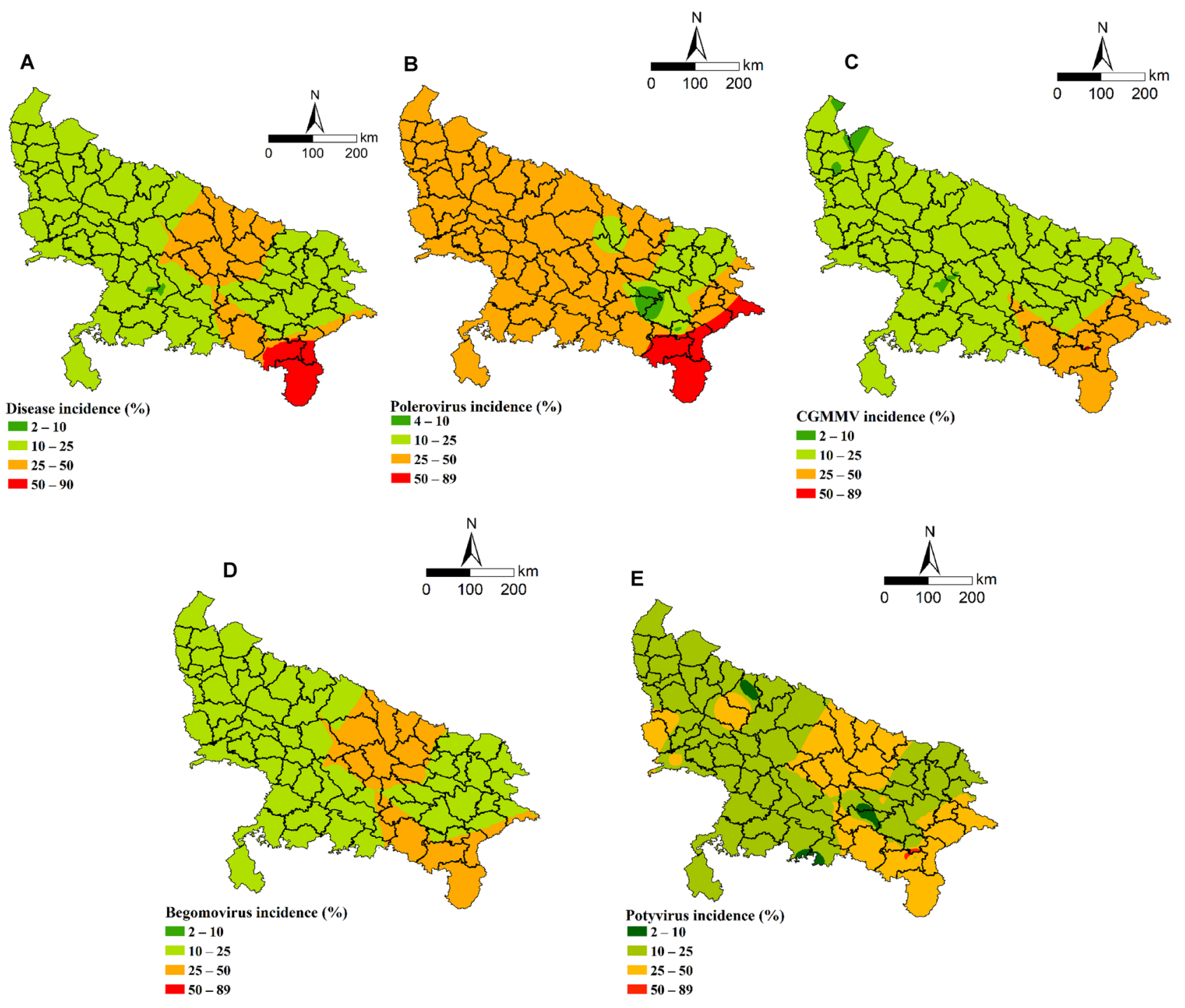

Figure 6. Map showing predicted distribution and incidence proportion of cucurbit viruses in the Uttar Pradesh state using ArcGIS 9.1 software.

\begin{tabular}{|c|c|c|c|c|c|c|c|c|c|c|c|}
\hline \multirow[b]{2}{*}{ Class } & \multirow[b]{2}{*}{ Disease incidence range } & \multicolumn{2}{|c|}{ Potyvirus } & \multicolumn{2}{|c|}{ Polerovirus } & \multicolumn{2}{|c|}{ Begomovirus } & \multicolumn{2}{|c|}{ CGMMV } & \multicolumn{2}{|c|}{$\begin{array}{l}\text { Overall disease } \\
\text { incidence }\end{array}$} \\
\hline & & Pixels & $\%$ area & Pixels & $\%$ area & Pixels & $\%$ area & Pixels & $\%$ area & Pixels & $\%$ area \\
\hline 1 & $2-10$ & 536 & 1.68 & 489 & 1.53 & 1 & 0.00 & 637 & 1.99 & 126 & 0.39 \\
\hline 2 & $10-25$ & 21,111 & 66.01 & 4122 & 12.89 & 23,904 & 74.73 & 26,454 & 82.71 & 23,887 & 74.66 \\
\hline 3 & $25-50$ & 10,271 & 32.11 & 25,043 & 78.30 & 8068 & 25.22 & 4881 & 15.26 & 6518 & 20.37 \\
\hline 4 & $50-89$ & 65 & 0.20 & 2329 & 7.28 & 16 & 0.05 & 11 & 0.03 & 1462 & 4.57 \\
\hline \multicolumn{2}{|l|}{ Total } & 31,983 & 100.00 & 31,983 & 100.00 & 31,989 & 100.00 & 31,983 & 100.00 & 31,993 & 100.00 \\
\hline
\end{tabular}

Table 3. Percentage of area categorized under each disease incidence category.

\section{Materials and methods}

Sample collection and analysis. An intensive study was conducted on cucurbitaceous crops during the cropping seasons in 2018 from all nine agro-climatic zones of Uttar Pradesh state, India (Fig. 2). Around 200 farmers' fields were visited during the sampling and a total of 563 samples from 14 different cucurbit crops suspected to have virus infection were collected by following relevant guidelines and permission from respective farmers for analysis (Supplementary Table 1; Supplementary Fig. 2). Percent disease incidence per field was estimated based on the number of plants showing symptoms and the total number of plants observed. 


\begin{tabular}{|c|c|c|c|c|c|}
\hline Primer ID & $5^{\prime}-3^{\prime}$ sequence & Target virus & Target region & Amplicon size (bp) & References \\
\hline PNIbF1 & GGBAAYAATAGTGGNCAACC & \multirow{4}{*}{ Potyvirus } & \multirow{2}{*}{ NIB and CP } & \multirow{2}{*}{$\sim 1100$} & \multirow{2}{*}{17} \\
\hline PCPR1 & GGGGAGGTGCCGTTCTCDATRCACCA & & & & \\
\hline NIb2F & GTITGYGTIGAYGAYTTYAAYAA & & NUB & & 18 \\
\hline NIb3R & TCIACIACIGTIGAIGGYTGNCC & & NIB & $\sim 350$ & 18 \\
\hline GK PRSV F & GCAATGATAGARTC ATGGGG & \multirow{2}{*}{ PRSV } & \multirow{2}{*}{$\mathrm{CP}$} & \multirow{2}{*}{1264} & \multirow{2}{*}{15} \\
\hline GK PRSV R & AAGCGGTGGCGCAGCCACACT & & & & \\
\hline GK ZYMV F & ATAGCTGAGACA GCACT & \multirow{2}{*}{ ZYMV } & \multirow{2}{*}{$\mathrm{CP}$} & \multirow{2}{*}{1004} & \multirow{2}{*}{5} \\
\hline GK ZYMV R2 & CGGCAGCRAAACGATAACCT & & & & \\
\hline CMV 1 & GATCATCGCCTGAGAATA & \multirow{2}{*}{ CMV } & \multirow{2}{*}{$2 \mathrm{a}$} & \multirow{2}{*}{$\sim 400$} & \multirow{2}{*}{19} \\
\hline CMV 2 & TTCCAGAGATGCCTTCG & & & & \\
\hline gL3637 & CCTTTAACAGTDGAAACAT & \multirow{2}{*}{ Orthotospovirus } & \multirow{2}{*}{ RdRp } & \multirow{2}{*}{$\sim 800$} & \multirow{2}{*}{20} \\
\hline gL 4435c & CATDGCRCAAGARTGRTARACAGA & & & & \\
\hline GK PBNV CP F & ATGTCTAACGTYAAGCAGCTC & \multirow{2}{*}{ GBNV } & \multirow{2}{*}{$\mathrm{CP}$} & \multirow{2}{*}{$\sim 900$} & \multirow{2}{*}{21} \\
\hline GK PBNV CP R & TTACAATTCCAGCGAAGGAC & & & & \\
\hline GK WBNV CP F & AATAAACTAATGACACACACAAA & \multirow{2}{*}{ WBNV } & \multirow{2}{*}{$\mathrm{CP}$} & \multirow{2}{*}{$\sim 950$} & \multirow{2}{*}{22} \\
\hline GK WBNV CP R & ACGTTTCCAKAGTAAACACCAT & & & & \\
\hline GK CGMMV F & TAAG CGGCATTCTAAACCTCCA & \multirow{2}{*}{ CGMMV } & \multirow{2}{*}{$\mathrm{CP}$} & \multirow{2}{*}{604} & \multirow{2}{*}{6} \\
\hline GK CGMMV R & CACTATGCACTTTG GTGTGC & & & & \\
\hline PolGenUp2 & GATGARGGTCGYTACCG & \multirow{2}{*}{ Polerovirus } & CP & 593 & 23 \\
\hline PolGenDown2 & ACCTCGACTTTRAARCC & & CP & 393 & \\
\hline Potex 2RC & AGCATRGCNSCRTCYTG & Potexvirue & & -600 & 24 \\
\hline Potex 5 & CAYCARCARGCMAARGAYGA & Potexvirus & & $\sim 600$ & \\
\hline CriniRdRp251F & TNGGNAARGGNGARAG & Crinivirus & $\mathrm{BdRn}$ & $\sim 800$ & 25 \\
\hline CriniRdRp 995R & GTRTTNGAYAACCAHGTRTTHG & Crinivirus & RdRp & $\sim 800$ & \\
\hline PAL1c1960 & ACNGGNAARACNATGTGGGC & Beoomovirus & $\mathrm{ACl}$ and $\mathrm{AC} 2$ & $\sim 120$ & 26 \\
\hline PAR1v722 & GGNAARATHTGGATGGA & Begomovirus & AC1 and AC2 & $\sim 1200$ & \\
\hline
\end{tabular}

Table 4. Details of primers used in this study.

Detection of begomovirus. Total DNA was extracted from leaf tissues (100 mg) of both symptomatic and non-symptomatic plants using the cetyl trimethyl ammonium bromide (CTAB) method as described by Doyle and Doyle ${ }^{35}$ and subjected to PCR amplification using universal Begomovirus primer pair PAL1c1960/ PAR1v722 (Table 4).

Detection of RNA viruses. Total RNA was extracted from $100 \mathrm{mg}$ of each symptomatic and apparently healthy leaf samples using TriReagent (Sigma Aldrich, USA). Total RNA was subjected to reverse-transcription polymerase chain reaction (RT-PCR) for the preparation of cDNA using the RevertAid First Strand cDNA synthesis kit (Thermo Scientific, USA) according to the manufacturer's instructions. Prepared cDNA was used for virus detection through PCR amplification using specific primers (Table 4).

Cloning, sequencing and sequence analysis. Amplified PCR products of representative samples were purified using the QIAquick Gel Extraction Kit (Qiagen) and cloned in the pGEM-T Easy Vector System (Promega Corp. ${ }^{36}$. Plasmid DNA preparations were obtained using Wizard Plus Minipreps DNA Purification (Promega Corp). Two clones were selected from each sample for sequencing and sequencing was performed at the Delhi University-South campus, New Delhi (India). Sequences were analyzed using the Basic Local Alignment Search Tool (BLAST) for the identification of virus at species level ${ }^{37}$. The top three to five hits against each database were included in the analysis for each sequence. The molecular evolutionary genetics analysis software (MEGA, version 7) was employed to determine the phylogenetic relationship of the study isolates with the earlier reported viruses using the neighbour joining method $^{38}$.

Application of ArcGIS for disease mapping. The GPS (geographical positioning system) data and disease incidence data of the explored areas were collected to be used for mapping the epidemiological distribution and incidence proportion of viruses infecting cucurbit crops. The spatial variability maps of Polerovirus, CGMMV, Potyvirus, Begomovirus and overall disease incidence in nine agro-climatic zones were prepared using Geostatistical Analyst extension in ArcGIS 9.1 software. Inverse distance weighted (IDW) method was used for interpolation. The IDW is a simple interpolation technique which is based on the assumption that the variable values at unmeasured locations are influenced most by nearby observation points and less by distant points. This technique assumes that each measured location has a local effect, which reduces with distance by means of the utilization of a power parameter ${ }^{39}$. The formula of $\mathrm{IDW}^{40}$ is given as follows: 


$$
\hat{\mathrm{Z}}\left(\mathrm{S}_{0}\right)=\sum_{\mathrm{i}=1}^{\mathrm{n}} \lambda_{\mathrm{i}} \mathrm{Z}\left(\mathrm{S}_{\mathrm{i}}\right)
$$

where $\hat{Z}\left(S_{0}\right)$ is the predicted value at location $S_{0}, n$ is the number of measured sample points surrounding the prediction location, $\lambda_{\mathrm{i}}$ is the weight assigned to each measured point, $Z\left(\mathrm{~S}_{\mathrm{i}}\right)$ is the observed value at the location $\mathrm{S}_{\mathrm{i}}$.

The formula to calculate the weights is given as follows:

$$
\lambda_{\mathrm{i}}=\frac{\mathrm{d}_{\mathrm{i} 0}^{-\mathrm{p}}}{\sum_{\mathrm{i}=1}^{\mathrm{n}} \mathrm{d}_{\mathrm{i} 0}^{-\mathrm{p}}}
$$

$p$ is power parameter which reduces with increasing distance, $d_{i 0}$ is the distance between the prediction location $\left(\mathrm{S}_{0}\right)$ and each of the measured locations $\left(\mathrm{S}_{\mathrm{i}}\right)$.

The optimal power value of IDW was estimated using root mean square error of cross-validation (RMSECV). Power value with the lowest RMSECV was selected for IDW interpolation ${ }^{41}$. A variable search radius with maximum of 15 sample points and minimum of 10 sample points was used.

Received: 22 March 2021; Accepted: 3 August 2021

Published online: 09 September 2021

\section{References}

1. Jeffrey, D. Appendix: An outline classification of the Cucurbitaceae. In Biology and Utilization of the Cucurbitaceae (eds Bates, D. M. et al.) (Cornell University, 1990).

2. Horticultural Statistics at a Glance 2018. Available online: agricoop.nic.in/sites/default/files/Horticulture\%20Statistics\%20at $\% 20$ a\%20Glance-2018.pdf

3. Lecoq, H. \& Katis, N. Control of cucurbit viruses. Adv. Virus Res. 90, 255-296. https://doi.org/10.1016/B978-0-12-801246-8. 00005-6 (2014).

4. Mansilla, P. J. et al. Importance of cucurbits in the epidemiology of Papaya ringspot virus type P. Plant Pathol. 62, 571-577 (2013).

5. Nagendran, K. et al. First report of Zucchini yellow mosaic virus in snake gourd (Trichosanthes cucumerina) in India. Plant Dis. 99(4), 558 (2015).

6. Nagendran, K. et al. First report of Cucumber green mottle mosaic virus in snake gourd (Trichosanthes cucumerina) in India. Plant Dis. 99(4), 559 (2015).

7. Sobh, H. et al. First report of Squash leaf curl virus in cucurbits in Lebanon. Dis. Notes 96(8), 1231 (2012).

8. Dreher, T. W. et al. Tymoviridae. In Virus Taxonomy: Ninth Report of the International Committee on Taxonomy of Viruses (eds King, A. M. Q. et al.) 901-952 (Academic Press, 2012).

9. Abdalla, O. A., Bruton, B. D., Fish, W. W. \& Ali, A. First confirmed report of Tobacco ringspot virus in cucurbits crops in Oklahoma. Plant Dis. 96, 1705 (2012).

10. Zitter, T. A. \& Murphy, J. F. Cucumber mosaic. Plant Health Instr. https://doi.org/10.1094/PHI-I-2009-0518-01 (2009).

11. Liu, Y., Wang, Y., Wang, X. \& Zhou, G. Molecular Characterization and Distribution of Cucumber green mottle mosaic virus in China. J. Phytopathol. 157, 393-399 (2009).

12. Reingold, V., Lachman, O., Blaosov, E. \& Dombrovsky, A. Seed disinfection treatments do not sufficiently eliminate the infectivity of Cucumber green mottle mosaic virus (CGMMV) on cucurbit seeds. Plant Pathol. https://doi.org/10.1111/ppa.12260 (2014).

13. Simmons, H. E., Holmes, E. C., Gildow, F. E., Bothe-Goralczyk, M. A. \& Stephenson, A. G. Experimental verification of seed transmission of Zucchini yellow mosaic virus. Plant Dis. 95, 751-754 (2011).

14. Tobias, I. et al. Seed borne transmission of Zucchini yellow mosaic virus and Cucumber mosaic virus in Styrian Hulless group of Cucurbita pepo. In Proceeding IXth EUCARPA Meeting of Genetics and Plant Breeding of Cucurbitaceae (ed. Pitrat, M.) 189-197 (INRA, 2008).

15. Nagendran, K. et al. The occurrence and distribution of major viruses infecting cucurbits in Tamil Nadu state, India. Crop Prot. 99, 10-16 (2017).

16. Chikh-Ali, M., Natsuaki, T. \& Karasev, A. V. Molecular diversity of main cucurbit viruses in Syria. J. Plant Pathol. 101(4), 1067-1075 (2019).

17. Hsu, Y. C., Yeh, T. J. \& Chang, Y. C. A new combination of RT-PCR and reverse dot blot hybridization for rapid detection and identification of potyviruses. J. Virol. Methods 128(1-2), 54-60 (2005).

18. Zheng, L. et al. Accumulating variation at conserved sites in potyvirus genomes is driven by species discovery and affects degenerate primer design. PLoS ONE 3(2), e1586 (2008).

19. Anonymous Detection and biodiversity of cucumber mosaic cucumovirus. Conclusions from a ringtest of european union cost 823 (new technologies to improve phytodiagnosis). J. Plant Pathol. 80(2), 133-149 (1998).

20. Chu, F. H., Chao, C. H., Chung, M. H., Chen, C. C. \& Yeh, S. D. Completion of the genome sequence of Watermelon silver mottle virus and utilization of degenerate primers for detecting tospoviruses in five serogroups. Phytopathology 91(4), 361-368 (2001).

21. Nagendran, K. et al. First report of peanut bud necrosis virus infecting bitter gourd (Momordica charantia L.) in India. Plant Dis. 102(3), 690-690 (2018).

22. Priyanka, R. et al. Characterization and management of watermelon bud necrosis virus infecting watermelon in India. Eur. J. Plant Pathol. 153(3), 759-770 (2019).

23. Lotos, L., Efthimiou, K., Maliogka, V. I. \& Katis, N. I. Generic detection of poleroviruses using an RT-PCR assay targeting the RdRp coding sequence. J. Virol. Methods 198, 1-11 (2014).

24. Van der Vlugt, R. A. \& Berendsen, M. Development of a general potexvirus detection method. Eur. J. Plant Pathol. 108(4), 367-371 (2002).

25. Wintermantel, W. M. \& Hladky, L. L. Methods for detection and differentiation of existing and new crinivirus species through multiplex and degenerate primer RT-PCR. J. Virol. Methods 170(1-2), 106-114 (2010).

26. Chatchawankanphanich, O. \& Maxwell, D. P. Tomato leaf curl Karnataka virus from Bangalore, India, appears to be a recombinant begomovirus. Phytopathology 92(6), 637-645 (2002).

27. Ali, A., Mohammad, O. \& Khattab, A. Distribution of viruses infecting cucurbit crops and isolation of potential new virus-like sequences from weeds in Oklahoma. Plant Dis. 96(2), 243-248 (2012).

28. Nagendran, K. et al. First report of natural occurrence of watermelon bud necrosis virus (WBNV) in round melon (Praecitrullus fistulosus (Stocks) Pangalo) in India. Plant Dis. 103(4), 781 (2019). 
29. Suveditha, S., Bharathi, L. K. \& Krishna Reddy, M. First report of Cucurbit aphid-borne yellows virus infecting bitter gourd (Momordica charantia) and teasel gourd (Momordica subangulata subsp. renigera) in India. New Dis. Rep. 36, 7 (2017).

30. Sangeetha, B., Malathi, V. G. \& Renukadevi, P. Emergence of Cucurbit aphid-borne yellows virus in bitter gourd (Momordica charantia) in Tamil Nadu, India. Plant Dis. 103(6), 1441 (2019).

31. Kone, N., Asare-Bediako, E., Koita, O., Kone, D. \& Winter, S. Seasonal and spatial variation in the prevalence of viral diseases and associated aphid-borne viruses in cucurbits in Cote d'Ivoire. Ann. Agric. Sci. 62(2), 227-234 (2017).

32. Bananej, K. \& Vahdat, A. Identification, distribution and incidence of viruses in field-grown cucurbit crops of Iran. Phytopathol. Mediterr. 47(3), 247-257 (2008).

33. Jeefoo, P., Tripathi, N. K. \& Souris, M. Spatio-temporal diffusion pattern and hotspot detection of dengue in Chachoengsao province, Thailand. Int. J. Environ. Res. Public Health 8(1), 51-74 (2011).

34. Osei, F. B. \& Duker, A. A. Spatial and demographic patterns of cholera in Ashanti region-Ghana. Int. J. Health Geogr. 7(1), 1-10 (2008).

35. Doyle, J. J. \& Doyle, J. L. Isolation ofplant DNA from fresh tissue. Focus 12(13), 39-40 (1990).

36. Sambrook, J., Fritsch, E. F. \& Maniatis, T. Molecular Cloning: A Laboratory Manual 2nd edn. (Cold Spring Harbor Laboratory Press, 1989).

37. Altschul, S. F., Gish, W., Miller, W., Myers, E. W. \& Lipman, D. J. Basic local alignment search tool. J. Mol. Biol. 215(3), 403-410 (1990).

38. Kumar, S., Stecher, G. \& Tamura, K. MEGA7: Molecular evolutionary genetics analysis version 7.0 for bigger datasets. Mol. Biol. Evol. 33(7), 1870-1874 (2016).

39. Johnston, K., VerHoef, J. M., Krivoruchko, K. \& Lucas, N. Using ArcGIS Geostatistical Analyst (Redlands, 2001).

40. Pingale, S. M., Khare, D., Jat, M. K. \& Adamowski, J. Spatial and temporal trends of mean and extreme rainfall and temperature for the 33 urban centers of the arid and semi-arid state of Rajasthan, India. Atmos. Res. 138, 73-90 (2014).

41. Johnston, K. ArcGIS 9: Using ArcGIS Geostatistical Analyst (ESRI Press, 2004).

\section{Acknowledgements}

Authors are thankful to Dr. Debashis Chakraborty, ICAR-IARI, New Delhi for facilitating us in QGIS data analysis and Dr. Stephen Wegulo, University of Nebraska-Lincoln for helping us in editing the manuscript. Further authors are very much thankful to the Director, ICAR-IIVR, Varanasi for facilitating to conducting the research and for funding publication charges.

\section{Author contributions}

K.K.P. and J.S. conceived and conceptualized the study. S.K. and K.N. conducted experiments, analysed data and wrote the manuscript. V.D. collected infected samples from farmers's field for analysis. B.D. made the QGIS data analysis. All the authors read the manuscript.

\section{Competing interests}

The authors declare no competing interests.

\section{Additional information}

Supplementary Information The online version contains supplementary material available at https://doi.org/ 10.1038/s41598-021-97232-4.

Correspondence and requests for materials should be addressed to S.K.

Reprints and permissions information is available at www.nature.com/reprints.

Publisher's note Springer Nature remains neutral with regard to jurisdictional claims in published maps and institutional affiliations.

(c) (i) Open Access This article is licensed under a Creative Commons Attribution 4.0 International License, which permits use, sharing, adaptation, distribution and reproduction in any medium or format, as long as you give appropriate credit to the original author(s) and the source, provide a link to the Creative Commons licence, and indicate if changes were made. The images or other third party material in this article are included in the article's Creative Commons licence, unless indicated otherwise in a credit line to the material. If material is not included in the article's Creative Commons licence and your intended use is not permitted by statutory regulation or exceeds the permitted use, you will need to obtain permission directly from the copyright holder. To view a copy of this licence, visit http://creativecommons.org/licenses/by/4.0/.

(C) The Author(s) 2021, corrected publication 2021 